\title{
Surface proteomic analysis of osteosarcoma identifies EPHA2 as receptor for targeted drug delivery
}

\author{
$\mathrm{J}$ PosthumaDeBoer ${ }^{1}$, S R Piersma ${ }^{2}$, T V Pham ${ }^{2}, \mathrm{P}$ W van Egmond ${ }^{1}$, J C Knol ${ }^{2}$, A M Cleton-Jansen ${ }^{3}$, \\ M A van Geer $^{4}$, V W van Beusechem ${ }^{5}$, G J L Kaspers ${ }^{6}$, B J van Royen ${ }^{1,7}$, C R Jiménez ${ }^{\star 2,8}$ \\ and $\mathrm{M}$ N Helder ${ }^{\star}, 1,7,8$
}

\begin{abstract}
${ }^{1}$ Department of Orthopaedic Surgery, VU University Medical Center, PO Box 7057, 1007 MB Amsterdam, The Netherlands; ${ }^{2}$ OncoProteomics Laboratory, Department of Medical Oncology, VU University Medical Center, PO Box 7057, 1007 MB, Amsterdam, The Netherlands; ${ }^{3}$ Department of Pathology, Leiden University Medical Center (LUMC), PO Box 9600,2300 RC Leiden, The Netherlands; ${ }^{4}$ Tytgat Institute for Liver and Intestinal Research, Academic Medical Center (AMC), Meibergdreef 69-71, 1105 BK Amsterdam, The Netherlands; ${ }^{5}$ Department of Medical Oncology, VU University Medical Center, PO Box 7057, 1007 MB, Amsterdam, The Netherlands; ' $P$ Paediatric Oncology/Haematology, VU University Medical Center, PO Box 7057, 1007 MB, Amsterdam, The Netherlands and ${ }^{7}$ Research Institute MOVE/Skeletal Tissue Engineering Group Amsterdam (STEGA), PO Box 7057, 1007 MB Amsterdam, The Netherlands
\end{abstract}

Background: Osteosarcoma (OS) is the most common bone tumour in children and adolescents. Despite aggressive therapy regimens, treatment outcomes are unsatisfactory. Targeted delivery of drugs can provide higher effective doses at the site of the tumour, ultimately improving the efficacy of existing therapy. Identification of suitable receptors for drug targeting is an essential step in the design of targeted therapy for OS.

Methods: We conducted a comparative analysis of the surface proteome of human OS cells and osteoblasts using cell surface biotinylation combined with nano-liquid chromatography - tandem mass spectrometry-based proteomics to identify surface proteins specifically upregulated on OS cells. This approach generated an extensive data set from which we selected a candidate to study for its suitability as receptor for targeted treatment delivery to OS. First, surface expression of the ephrin type-A receptor 2 (EPHA2) receptor was confirmed using FACS analysis. Ephrin type-A receptor 2 expression in human tumour tissue was tested using immunohistochemistry. Receptor targeting and internalisation studies were conducted to assess intracellular uptake of targeted modalities via EPHA2. Finally, tissue micro arrays containing cores of human OS tissue were stained using immunohistochemistry and EPHA2 staining was correlated to clinical outcome measures.

Results: Using mass spectrometry, a total of 2841 proteins were identified of which 156 were surface proteins significantly upregulated on OS cells compared with human primary osteoblasts. Ephrin type-A receptor 2 was highly upregulated and the most abundant surface protein on OS cells. In addition, EPHA2 was expressed in a vast majority of human OS samples. Ephrin type-A receptor 2 effectively mediates internalisation of targeted adenoviral vectors into OS cells. Patients with EPHA2-positive tumours showed a trend toward inferior overall survival.

Conclusion: The results presented here suggest that the EPHA2 receptor can be considered an attractive candidate receptor for targeted delivery of therapeutics to OS.

\footnotetext{
*Correspondence: Dr MN Helder; E-mail: m.helder@vumc.nl or Dr CR Jiménez; E-mail: c.jimenez@vumc.nl

${ }^{8}$ These authors contributed equally to this work.
}

Revised 23 August 2013; accepted 28 August 2013; published online 24 September 2013

(c) 2013 Cancer Research UK. All rights reserved 0007-0920/13 
Osteosarcoma (OS) is the most common primary malignant bone tumour in children and adolescents. The treatment for OS currently consists of a combination of multi-agent induction chemotherapy, radical excision of the tumour and metastases (when feasible), followed by adjuvant chemotherapy. Despite this aggressive regimen, the survival for patients affected by this tumour remains unsatisfactory. In patients with localised disease, 5 -year survival rates of approximately $65 \%$ are obtained, however, in the case of metastatic or recurrent disease, 5-year survival rates are reduced to only 20\% (Bielack et al, 2002; Hughes, 2009). Clearly, new, more effective treatment regimens are desirable for OS, preferentially enhancing the existing regimens. In the recent past, so-called targeted therapy has gained tremendous interest in anticancer treatment, exploiting tumour-specific molecules for therapeutic goals. In the case of cancer-specific treatment by targeted delivery of drugs, therapy should ideally be targeted to a cell surface molecule that is specific for the tumour and is highly expressed on the surface of tumour cells, but not on healthy tissues. The identification of suitable receptors for targeted delivery of therapeutics to OS is essential in the design and development of novel targeted treatment strategies. In this work, we aimed to identify surface markers that are specifically upregulated on OS by performing a proteomic analysis of the surface proteomes of OS cells compared with human primary osteoblasts (hp-OBs) using a mass spectrometry approach. Mass spectrometry-based proteomics has made enormous and rapid technical advancements over the past decade and currently allows for comprehensive comparative analyses to systematically identify and quantify thousands of proteins across multiple biological samples, for example, between tumour cells vs healthy controls (Wu and Yates, III, 2003; Cox and Mann, 2007; Pham et al, 2012).

Cell surface molecules are known to be involved in important biological processes, including proliferation, differentiation, migration and survival (Stevens and Arkin, 2000; Wu and Yates, III, 2003; Scheurer et al, 2005; Lund et al, 2009; Zhang et al, 2009). Also, surface molecules such as growth factor receptors, cytokines, metalloproteases and integrins are implicated in the development and progression of malignancies, including OS (Khanna et al, 2004; Krishnan et al, 2005; Kansara and Thomas, 2007; Guo et al, 2008; Kim et al, 2008; Wan et al, 2009; Rubin et al, 2010). Given their prominent role in cancer, surface proteins that are highly differentially expressed on OS cells compared with their healthy counterparts and can serve as potential delivery targets are likely to be found. Here, we present a comprehensive, mass spectrometry-based study of the surface proteome of OS, in which we identify multiple highly upregulated surface molecules that could potentially serve as receptors for the targeted delivery of drugs to OS. We select one candidate, the ephrin type-A receptor 2 (EPHA2), and show its potential as receptor for the intracellular delivery of targeted vectors to OS cells.

\section{MATERIALS AND METHODS}

Cell culture. Human OS cell lines MG-63, U2OS, Cal-72 (Rochet et al, 1999), SaOS-2 and SaOS-LM7 (Jia et al, 1999; LM7) were kindly provided by Dr C Löwik (Leiden University Medical Center, Leiden, The Netherlands), Dr S Lens (Dutch Cancer Institute, Amsterdam, The Netherlands), Dr J Gioanni (Faculté de Medicine, Nice, France), Dr F van Valen (Westfalische Wilhelms-Universität, Münster, Germany) and Professor Dr ES Kleinerman (MD Anderson Cancer Center, Houston, TX, USA), respectively. Human primary (short-term culture; i.e., passage $<10$ ) osteoblasts (ORT-1, Hum31, Hum54, Hum63 and Hum65) were obtained from healthy patients undergoing total knee replacement after informed consent. All cells, with the exception of LM7, were cultured in DMEM (Gibco, Invitrogen, Carlsbad, CA, USA) supplemented with $10 \%$ fetal calf serum (FCS) and $1 \mathrm{mg} \mathrm{ml}^{-1}$ penicillin-streptomycin (Gibco, Invitrogen) at $37^{\circ} \mathrm{C}$ and $5 \% \mathrm{CO}_{2}$ in a humidified incubator. LM7 was cultured in Eagle's-MEM supplemented with $10 \%$ FCS, $1 \mathrm{mg} \mathrm{ml}^{-1}$ Pen-Strep, $1 \%$ nonessential amino acids, $1 \%$ sodium pyruvate, $2 \mathrm{nM}$ L-glutamine and $2 \%$ MEM-vitamin solution (Gibco, Invitrogen) at $37^{\circ} \mathrm{C}$ and $5 \% \mathrm{CO}_{2}$ in a humidified incubator.

Cell surface protein isolation and gel-electrophoresis. For the isolation and collection of surface proteins, we used the Pierce Cell Surface Protein Isolation Kit (ThermoScientific, Waltham, MA, USA), following the manufacturer's instructions adjusted according to the protocol described by De Wit et al (2012) (Figure 1A); Supplementary File S1 provides an elaborate description of the cell surface protein isolation and mass spectrometry protocol. Per biological replicate, $3 \times 10^{7}$ cells were cultured in five $75 \mathrm{~cm}^{2}$ flasks. In brief, the cells were with Sulfo-NHS-SS-Biotin for $30 \mathrm{~min}$ at $4{ }^{\circ} \mathrm{C}$ after which the biotinylation reaction was quenched. The cells were washed, harvested by gentle scraping and lysed using the provided lysis buffer in the presence of a protease inhibitor cocktail (SigmaAldrich, St Louis, MO, USA). To capture biotinylated (surface) proteins, protein lysates were incubated with Neutravidin Agarose gel for $2 \mathrm{~h}$ in a column. The unbound (unbiotinylated) proteins, representing the intracellular fraction, were separated from the captured surface proteins by centrifugation of the column. The intracellular fraction was stored at $-20^{\circ} \mathrm{C}$ to serve as an internal control for the surface protein isolation process (see Supplementary File S1). Finally, the captured surface proteins were eluted from the biotin-Neutravidin Agarose by incubation with dithiothreitol in PBS. The eluted proteins, that is, the cell surface proteins, were collected by column centrifugation.

For all cell lines, three biological replicates were obtained; per cell line, the cell surface proteins were pooled and concentrated ten times using a Microcon YM-10 filter (Millipore, Billerica, MA, USA) to obtain adequate protein concentrations for gel-electrophoresis. Protein concentrations were quantified using the BCA protein Assay Kit (Pierce, ThermoScientific) and the lysates were stored at $-20{ }^{\circ} \mathrm{C}$ until use.

Cell surface protein lysate were separated by $1 \mathrm{D}$ gel-electrophoresis. The obtained gel was fixed in 50\% ethanol containing 3\% phosphoric acid for $1 \mathrm{~h}$, rinsed in Milli-Q water (MQ) and stained with Coomassie- $\mathrm{R} 250$ overnight $(\mathrm{O} / \mathrm{N})$ to visualise the protein bands. After staining, the gel was washed vigorously with MQ to rid the Coomassie and stored in MQ at $4{ }^{\circ} \mathrm{C}$ until further processing.

In-gel digestion and mass spectrometry. The proteins were further processed into tryptic peptides by in-gel digestion according to the protocol described by Piersma et al (2010), which was modified so that the pre-treatment phase of this protocol was applied to the whole gel instead of to protein fractions. This allows for as good retrieval of peptides while reducing the laboriousness of this procedure (Pham et al, 2012).

Peptide separation was performed by nano-liquid chromatography using an Ultimate 3000 nanoLC system (Dionex LC-Packings, Amsterdam, The Netherlands). Intact peptide MS spectra and MS/MS spectra were acquired on a LTQ-FT hybrid mass spectrometer (ThermoFisher, Bremen, Germany) as described in detail in (Albrethsen et al, 2010; Piersma et al, 2010; see Supplementary File S1).

Protein identification and quantification. To identify proteins from the acquired data, MS/MS spectra were searched against the human IPI database 3.62 (83.947 entries) using Sequest (version 27, rev 12, The Scripps Research Institute, La Jolla, CA, USA). Scaffold 3.00.04 (Proteomesoftware, Portland, OR, USA) was used to organise the gel-slice data and to validate peptide and protein identifications. For quantitative protein analysis, spectral counting (the number of assigned MS/MS spectra for each identified protein) was used. For quantification across samples, the spectral 

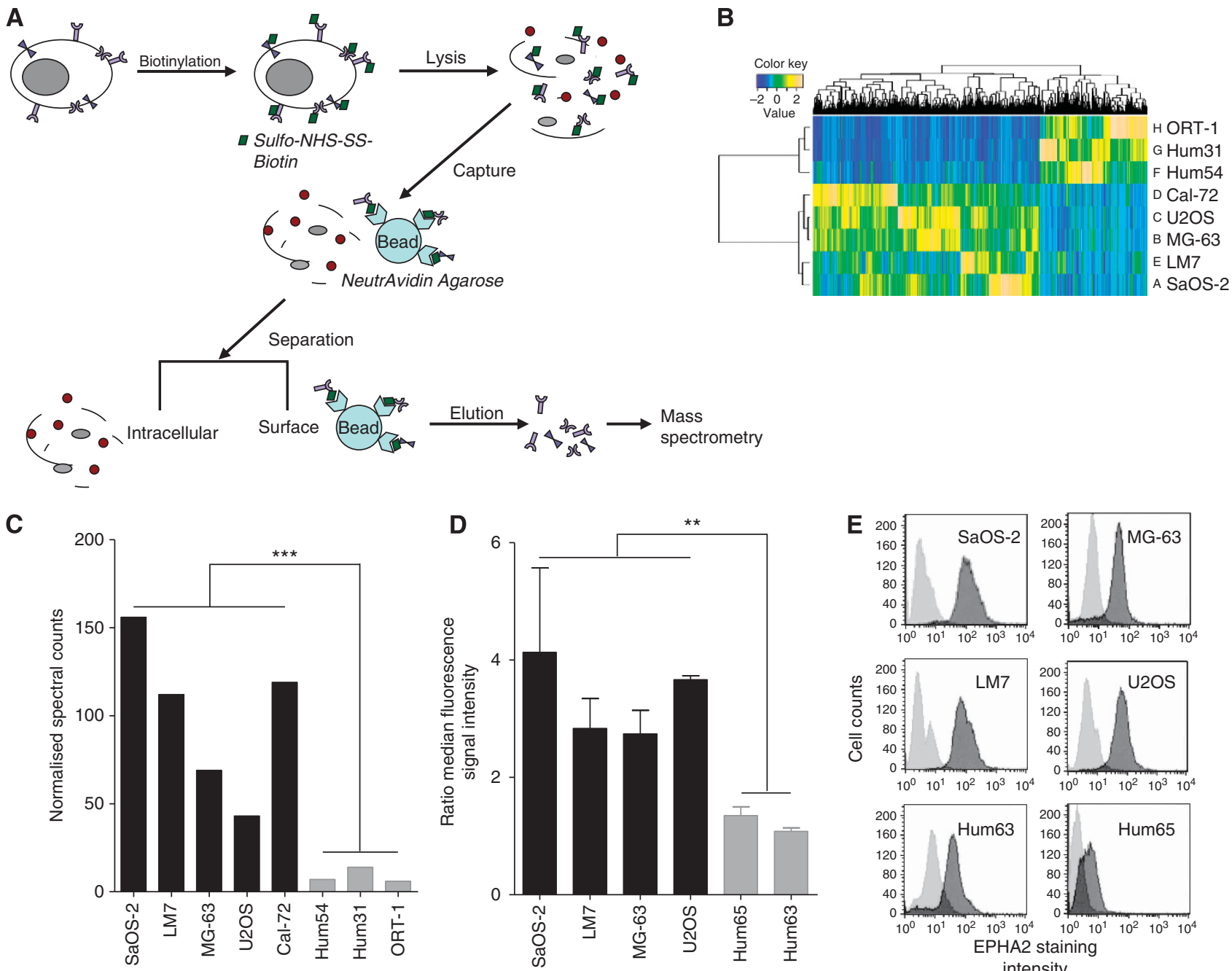

Figure 1. Cell surface protein isolation, visualisation of the proteomic data and EPHA2 expression levels. (A) General workflow of cell surface protein isolation. Cells were cultured in $75 \mathrm{~cm}^{2}$ culture flasks and incubated with Sulfo-NHS-SS-Biotin that covalently binds to primary amino groups of extracellular proteins. The cells were lysed and lysates were incubated with Neutravidin Agarose beads to capture the biotinylated proteins. The biotinylated (cell surface) proteins were separated from the unbound (intracellular) proteins by centrifugation on a column and then eluted from the biotin-Neutravidin Agarose beads using DDT. (B) A heat map of a supervised cluster analysis of our obtained data set, visualising the differentially expressed proteins (cutoff: $P<0.05$ ) between the three human primary OBs (Hum31, Hum54 and ORT-1) and the five OS cell lines (SaOS-2, MG-63, U2OS, Cal-72 and LM7). (C) EPHA2 expression data acquired by nanoLC-MS/MS. Differential expression of EPHA2 between the OS cell lines (black bars) and hp-OBs (grey bars) is evident, approximately 12-fold across the two types of cell, a difference that is highly significant (beta-binominal test; ${ }^{\star \star *} P=0.0005$ ). (D) EPHA2 expression data acquired by flow cytometry in OS cell lines SaOS-2, LM7, MG-63 and U2OS and hp-OBs Hum63 and Hum65, expressed as median (signal-to-background ratio) fluorescence intensities per cell line. Bars represent experiments performed in triplicate; error bars indicate s.d. The OS cell lines (black bars) show a convincingly higher EPHA2 expression than the hp-OBs (grey bars). On average, the OS cells were found to express four-fold higher levels of EPHA2 than the healthy bone cells and this difference is significant (Student's $t$-test; ${ }^{\star \star} P<0.01$ ). (E) Histograms of EPHA2 expression in OS cell lines; visualisation of flow cytometry results. Staining positivity for $\mathrm{EPHA} 2$ is indicated by an increase in fluorescent signal and a concomitant right shift of the histograms.

counts were normalised to the sum of the spectral counts per biological sample. Differential analysis of samples was performed using the beta-binominal test as described previously (Pham et al, 2010). Protein identification and quantification details can be found in (Pham et al, 2010; Piersma et al, 2010). The obtained data set was exported to Excel for further use.

Data mining. Subcellular protein localisations were verified using the Uniprot Knowledgebase (www.uniprot.org), searching under the header 'GO annotation' for evidence of expression at the cell and/or plasma membrane. Protein-protein interactions (PPIs) were investigated using the Search Tool for the Retrieval of Interacting Genes/Proteins (STRING) version 9.0 (www.string-db.org). For cluster and gene ontology (GO) analyses, we used the Cytoscape platform for network analysis (www.cytoscape.org), using the plugins CluterONE version 0.91 (http://chianti.ucsd.edu/cyto_web/ plugins/) for the clustering of proteins and BINGO version 2.44 (http://www.psb.ugent.be/cbd/papers/BiNGO/) for the analysis of $\mathrm{GO}$ annotations of biological processes associated with our obtained protein networks. In addition, verification of subcellular protein localisation was performed using Ingenuity pathway analysis software (IPA, Ingenuity Systems, Inc., Redwood City, CA, USA) and Biomart portal, version 7.0 (www.biomart.org).

FACS. Surface expression of EPHA2 on OS cells and hp-OBs was verified by flow cytometric analysis. Per sample, cells from three T25 culture flasks were harvested and pooled. Cells were trypsinised, washed in PBS containing $1 \%$ bovine serum albumin 
(BSA) and fixed in $70 \%$ ice-cold ethanol for $24 \mathrm{~h}$. After fixation, cells were washed in PBS with $1 \%$ BSA, incubated with $0.25 \mu \mathrm{g}$ mouse-anti-EPHA2 (Sigma-Aldrich) diluted in PBS containing 1\% BSA for $h$ at $4{ }^{\circ} \mathrm{C}$, rinsed and then incubated with the secondary FITC-conjugated rabbit-anti-mouse antibody (DAKO, Glostrup, Denmark) in PBS containing 1\% BSA for 30 min at RT in the dark. Finally, cells were rinsed and diluted in $200 \mu$ l PBS containing $1 \%$ BSA. Measurements were performed using a FacsCalibur II Flow Cytometer and the Cell Quest Pro programme (Becton Dickinson, Franklin Lakes, NJ, USA).

Receptor targeting and internalisation. To investigate EPHA2mediated intracellular uptake of targeted moieties, we performed internalisation and competition studies using AdYSA. AdYSA is a GFP-expressing, non-replicative adenoviral vector specifically targeting EPHA2 because of the insertion of a small peptide (YSA) with high EPHA2 binding-affinity into the HI loop of the adenovirus serotype 5 fibre knob. This insertion was combined with ablation of binding sites for the native adenoviral receptors CAR and $\alpha_{\mathrm{v}}$-integrins to further ensure specificity towards EPHA2 (Van Geer et al, 2010). Osteosarcoma cells and hp-OBs were plated in 96-well format and incubated with $100 \mu \mathrm{l}$ complete medium at multiplicities of infection (MOIs) ranging from 0.2 to 100 infectious units (IUs) per cell. Transduction efficiency was analysed after $48 \mathrm{~h}$ by fluorescence read-out using an Acumen ${ }^{\mathrm{e}} \mathrm{X} 3$ microplate cytometer (TTP LabTech Ltd, Melbourn, UK). Cells were incubated with $0.06 \mathrm{nM}$ Hoechst for $30 \mathrm{~min}$ at $37^{\circ} \mathrm{C}$ in the dark to stain nuclei. Cells were excited with a $405 \mathrm{~nm}$ laser for Hoechst (blue) and a $448 \mathrm{~nm}$ laser for GFP (green) and the emissions of the positive cells for Hoechst and GFP were counted in their respective channels. The ratio of GFP-positive to Hoechstpositive objects was used as the measure for transduction efficiency and recorded as percentages. AdGFP vector with native adenovirus serotype 5 tropism (MOI-10 and MOI-100) was used as a control for transduction for all cell lines.

Competition experiments were performed by the addition of synthetic YSA peptide (YSAPDSVPMMS) to the cells, thereby blocking the EPHA2 receptor-mediated uptake of AdYSA. The irrelevant peptide Cys.S (SSSKEENRIIPGG) was used as negative control. Cells were plated and pre-incubated with $250 \mu \mathrm{M}$ of either peptide in $50 \mu \mathrm{l}$ PBS for $20 \mathrm{~min}$ at RT. Then, $50 \mu \mathrm{l}$ of complete medium with AdYSA was added to the cells to a final MOI-100 and left to incubate for $30 \mathrm{~min}$ at $37^{\circ} \mathrm{C}$. The cells were washed with PBS and incubated with complete medium for $48 \mathrm{~h}$ after which transduction efficiency was analysed as described above.

FACS and Acumen data analysis was performed using GraphPad Prism Version 5.01 (GraphPad Software, Inc., San Diego, CA, USA).

Immunohistochemistry. Slides containing paraffin-embedded tissue samples of primary OS $(n=10)$, OS lung metastases $(n=8)$ and normal bone $(n=11)$ tissue were obtained from excision specimens from our institute. The primary tumours and metastases were not obtained from the same patients. The primary OS lesions comprise five biopsies (chemonaive) and five resections (after neo-adjuvant chemotherapy). All patients with metastatic lesions had received chemotherapy in an earlier phase of their disease, but had not yet received treatment for their metastases. The slides were deparaffinised in Xylene and rehydrated in a graded series of alcohol. Endogenous peroxidase activity was inhibited by incubation with $0.3 \% \mathrm{H}_{2} \mathrm{O}_{2}$ diluted in methanol for $30 \mathrm{~min}$. Tissue micro arrays (TMAs) were boiled in $10 \mathrm{mM}$ citrate buffer ( $\mathrm{pH} \mathrm{6)}$ for $10 \mathrm{~min}$ and subsequently rinsed in PBS. The slides were incubated with mouse-anti-EPHA2 (Sigma-Aldrich) $\mathrm{O} / \mathrm{N}$ at $4{ }^{\circ} \mathrm{C}$. Antigen visualisation was performed using the EnVision $^{+}$Poly-HRP IHC Kit (Immunologic, Duiven, The Netherlands) and DAB chromogen solution. Slides were counterstained with haematoxylin, dehydrated and mounted.
Tissue micro arrays. Two TMAs containing a total of 647 cores of human primary OS samples (corresponding to 130 OS patients) and 20 control tissue cores, were stained and analysed for EPHA2 expression (Supplementary Figure S1A) and then correlated to clinical and survival data. The TMAs were crafted at the Leiden University Medical Center (LUMC, Leiden, The Netherlands) according to the protocol described in Mohseny et al (2009). In brief, tissue cores were obtained from tumour areas selected by a pathologist based on a haematoxylin and eosin staining of each specimen, to assure that tumour tissue was sampled. A total of 144 fresh frozen paraffin-embedded OS samples were used. At least three cores per tumour were sampled in order to intercept intratumoural heterogeneity. All patients were treated for OS at the LUMC in the period between 1984 and 2009. Available clinical data includes: age, gender, location and side of the primary tumour, response to chemotherapy according to the Huvos grading system (Rosen et al, 1982; when available), metastasis, recurrence, date of recurrence, survival, date of death (when applicable) and time of follow-up. The TMA slides were heated at $60^{\circ} \mathrm{C}$ for $20 \mathrm{~min}$ before deparaffinisation and rehydration. Immunohistochemical staining followed as described above.

TMA scoring and analysis. The stained TMA slides were automatically scanned as described previously (PosthumaDeBoer et al, 2012). All 647 samples were independently examined and scored twice by two of the authors (JP and PWE), in two separate sessions. The scoring was performed using dedicated TMA scoring software (3DHISTECH Ltd, Budapest, Hungary) in a blinded manner. To facilitate the scoring and improve the reproducibility of scoring, a consensus chart with exemplary staining patterns per category was created (Supplementary Figure S1B) and used by the observers during scoring. The staining per tissue was assessed and valued as 'negative', 'weak', 'moderate' or 'positive'. Owing to loss of cores during the cutting and staining procedure, not all cores could be included for analysis. Samples were considered unsuitable for scoring when $<30 \%$ of tissue was present at the site of the core. In case of insufficient tissue, the cores were given the value 'no data'. The grading scale eventually consisted of five values $(0=$ no data; $1=$ negative; 2 =weak; $3=$ moderate; 4 = positive). Each tumour was represented by three cores on the TMAs allowing for a maximum of 12 observations per tumour (i.e., 3 cores $\times 2$ observers $\times 2$ scoring sessions). To assure reliable scoring per tumour sample, a tumour had to be assigned minimally 8 scores of 1 or higher (thus excluding 'no data' observations), to be included in the statistical analysis. We used the mean of the observations to assign the final staining score to each sample. The clinical data and the staining results were entered and statistically analysed in SPSS, version 17.0 (SPSS Software, Inc., Chicago, IL, USA). To assess inter- and intraobserver agreement in grading EPHA2 staining, kappa statistics were used. As inter- and intra-observer reproducibility may be biased by an overemphasis on patients with grade 0 findings, kappa values were therefore also calculated with the exclusion of grade 0 findings (censored kappa). Values between 0 and 1 were interpreted according to modified published guidelines (Supplementary Table S1; Landis and Koch, 1977; Altman, 1991). Kaplan-Meier analysis was used to assess survival and differential survival between groups was analysed using the log-rank test. To determine significant differences between categorical groups, the Pearson $\chi^{2}$ test was used. In numerical groups, the independent $t$-test and one-way ANOVA were used. The threshold for statistical significance was set at $P<0.05$.

\section{RESULTS}

Surface proteomics identifies proteins with differential abundance on OS cells and human primary OBs. In our search for surface proteins that could serve as receptors for targeted drug delivery to OS, 
we performed surface biotinylation of five OS cell lines and three human primary OBs for cell surface protein isolation and combined this with a comprehensive proteomics analysis using gel fractionation and mass spectrometry (Figure 1A). In total, 2841 proteins were identified in the eight different surface lysates (Supplementary Table S2). In all, 684 proteins were significantly upregulated in OS cells compared with hp-OBs $(P<0.05$; Figure $1 \mathrm{~B})$. A total of 151 proteins were confirmed as being cell surface proteins, based on their cellular component ontology term in the Uniprot Knowledgebase (www.uniprot.org). We further investigated PPIs, protein clusters, networks, subcellular localisations and the biological processes of a selected set of identified proteins, using the STRING 9.0 tool, Cytoscape software with packages ClusterONE and BINGO, and ingenuity pathway analysis. The results of these elaborate analyses are provided in Supplementary File S2 and Supplementary Tables S3 and S4. Proteins of interest were further selected as putative receptors for drug targeting to OS according to the following considerations: (1) $\mathrm{OS}$ is a heterogeneous tumour, therefore we applied a frequency filter stating that candidate surface proteins should be expressed consistently, that is, on all five analysed OS cell lines; (2) to ascertain a therapeutic window that is wide enough to realise a dose increase at the site of the tumour while sparing other tissues, candidate surface proteins should be $>10$-fold upregulated on OS compared with hp-OBs; and (3) to allow effective drug delivery, candidate surface receptors should be abundantly expressed. Abundance was defined as an average of $>5$ spectral counts (sc) per sample. When applying these criteria to our data set, we retrieved 97 cell surface proteins that were found to be expressed in 5 out of 5 OS cell lines; 55 of which were $>10$-fold upregulated in OS and, finally, 43 proteins were abundant (Table 1). These 43 proteins are considered promising candidate receptors for targeted drug delivery to OS. The hit list contains surface proteins that are well known in tumour biology, such as integrins, ephrins and ephrin receptors, growth factor receptors (i.e., the insulin receptor and the insulin-like growth factor 1 receptor), (proto)cadherins and various transmembrane transporters.

Among the selected hits, the EPHA2 was found to be the most abundant surface protein on OS cells, with an average of $100 \mathrm{sc}$ per OS cell line, significantly differentially expressed $(P=0.0005)$ and 12 -fold upregulated on OS cells compared with hp-OBs (Table 1; Figure 1C). Based on its abundance and degree of differential expression, we chose to further investigate the EPHA2 receptor for its suitability as a receptor for the targeted delivery of therapeutics to OS.

Validation of cell surface location of EPHA2 by FACS analysis. To validate our mass spectrometry data and ascertain high levels of cell surface localisation of EPHA2 on OS cells and low levels on hp-OBs, cells were subjected to FACS analysis. The measure of EPHA2 surface expression was defined as the ratio of median fluorescence signal intensity between EPHA2-labelled cells $v s$ non-labelled cells. Figure $1 \mathrm{D}$ shows that EPHA2 expression is considerably higher in OS cells compared with hp-OBs (Student's $t$-test; $P<0.01$ ), which is in concordance with our mass spectrometry data (Figure 1C). Figure 1E shows that all the tested OS cell lines convincingly express EPHA2, as we observe a substantial right shift of the histograms of the EPHA2-labelled cells compared with the control samples. Thus, the flow cytometry results confirm the primary mass spectrometry findings.

EPHA2 receptor targeting and uptake studies. To confirm that the EPHA2 receptor can be used for the specific delivery and uptake of targeted vectors to OS, we performed internalisation studies with AdYSA, a GFP-expressing, replication defective, adenoviral vector that was designed to specifically target EPHA2 (Van Geer et al, 2010). First, transduction efficiency on OS cells and hp-OBs was assessed. Cells were plated and subjected to increasing MOIs of AdYSA up to 100 IUs per cell. At 48-h postinfection, GFP expression was analysed. All OS cell lines showed a dose-dependent transduction by AdYSA. Contrarily, the hp-OBs were poorly transduced with AdYSA. Figure 2A shows typical fluorescence image overlays of two OS cell lines (SaOS-2 and MG-63) and one human primary OB (Hum63) subjected to different MOIs of AdYSA. As can be appreciated, SaOS-2 showed clear GFP expression already at a low MOI (6.25) and MG-63 is effectively transduced at higher MOI. In contrast, Hum63 showed a very low response to incubation with AdYSA. GFP expression was essentially absent, up to the highest virus dose used. The difference in transduction efficiency between the cell types was tested at MOI-100 (Figure 2B). Osteosarcoma cells showed a three- to six-fold higher GFP expression than hp-OBs, which was significant (Student's $t$-test; $P<0.05$ ). From this we conclude that vectors targeted to the EPHA2 receptor can be successfully internalised into EPHA2-expressing OS cells, whereas hp-OB cells scarcely expressing EPHA2 remain essentially unaffected.

To prove that AdYSA uptake is specifically mediated by the EPHA2 receptor, we performed competition experiments with synthetic YSA peptide. Cells were plated and pre-incubated with the synthetic YSA peptide to block EPHA2 receptor-mediated internalisation. As a control, cells were pre-incubated with an irrelevant peptide Cys.S and with AdYSA alone. Cells that were pre-incubated with YSA peptide showed a strong decrease in viral uptake compared with cells incubated with virus alone or cells treated with Cys.S peptide (Figure 2C). Blocking the receptor with YSA peptide reduced AdYSA transduction efficiency four- to seven-fold in different $O S$ cell lines (significance $P<0.001$ to $P<0.01$ ), whereas Cys.S peptide did not hamper the uptake of viral particles. This indicates that YSA peptide specifically blocks the EPHA2 receptor, thereby decreasing transduction by AdYSA. In hp-OBs that were essentially poorly transduced with AdYSA, no decrease in transduction efficiency by receptor blockage could be detected. Thus, internalisation of AdYSA into OS cells was indeed specifically mediated by the EPHA2 receptor.

Taken together, the data from these experiments demonstrate that targeted vectors can be internalised into OS cells via the EPHA2 receptor and that this uptake is convincingly higher in OS cells than in hp-OBs. Furthermore, the uptake of the targeted vector relies specifically on the EPHA2 receptor. Given the differential uptake and the specificity thereof, EPHA2 can be considered a putative receptor for the targeted delivery of treatment to OS.

EPHA2 is differentially expressed in human OS tissue compared with healthy bone tissue. To investigate whether EPHA2 is, in addition to on OS cell lines, also expressed on human OS tissue, we performed immunohistochemical staining on archival OS tumour sections $(n=18)$, including OS lung metastases $(n=8)$ and compared EPHA2 staining with healthy bone tissue $(n=11)$. Clinical details of the tested samples are provided in Supplementary Table S5. Figure 3A shows exemplary staining results of OS sections with positive, moderate and weak staining. The negative samples represent the normal bone sections. Among the OS specimens, $67 \%$ showed strong positive EPHA2 staining, $22 \%$ show a moderately positive staining and $11 \%$ stained negative (Figure 3B). All but one metastatic lesions (87\%) stained positive for EPHA2. We predominantly observed mixed cytoplasmic and plasma membrane staining patterns. In contrast, none of the healthy bone specimens showed clear positivity for EPHA2. Two bone specimens (18\%) had a weak staining intensity and 1 (9\%) stained moderately positive. In summary, the staining results confirm that there is a significant differential EPHA2 expression on human OS tissue compared with normal bone ( $\chi^{2}$ test; $P<0.005$ ). When analysed separately both primary and metastatic lesions 


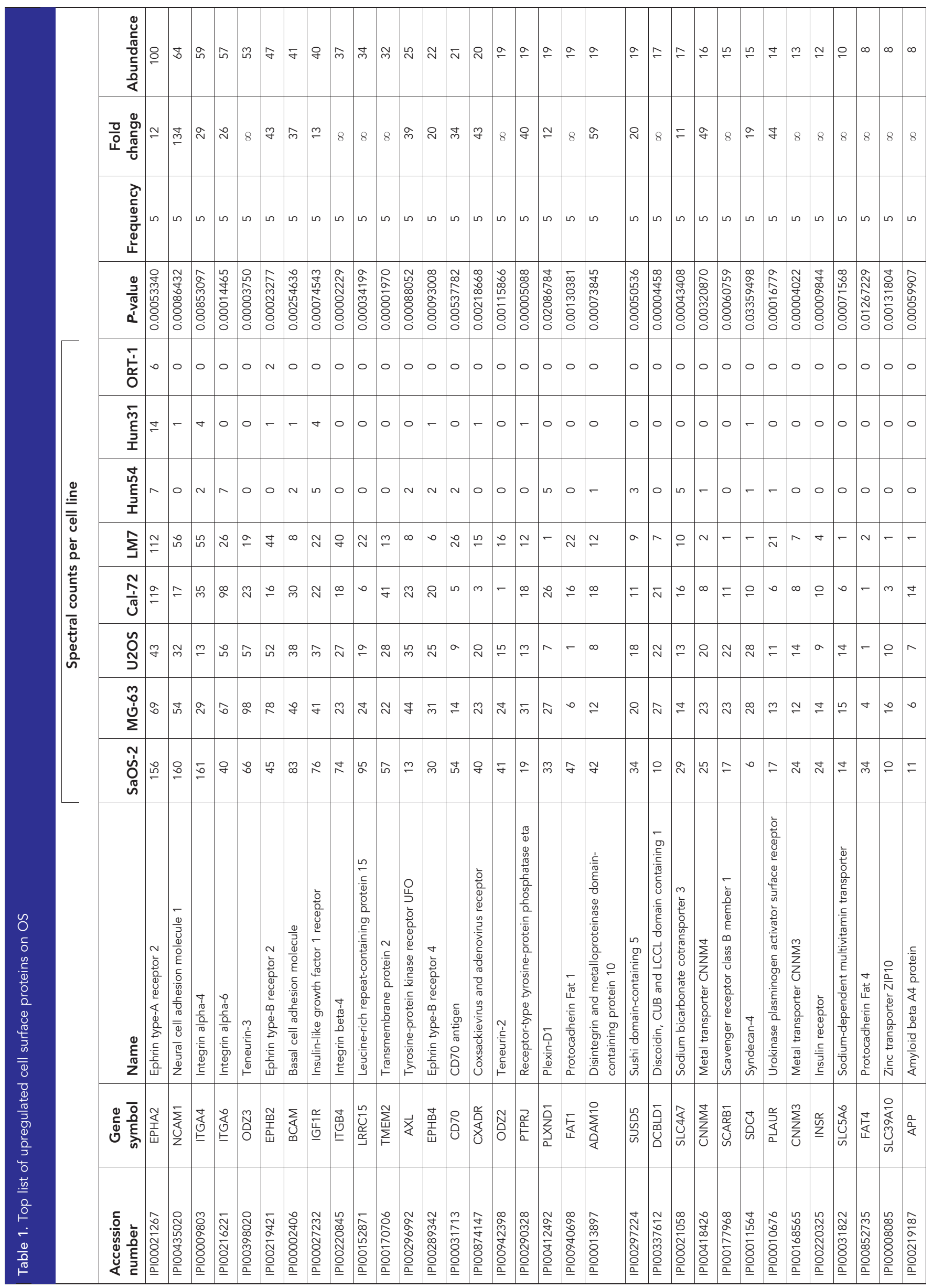




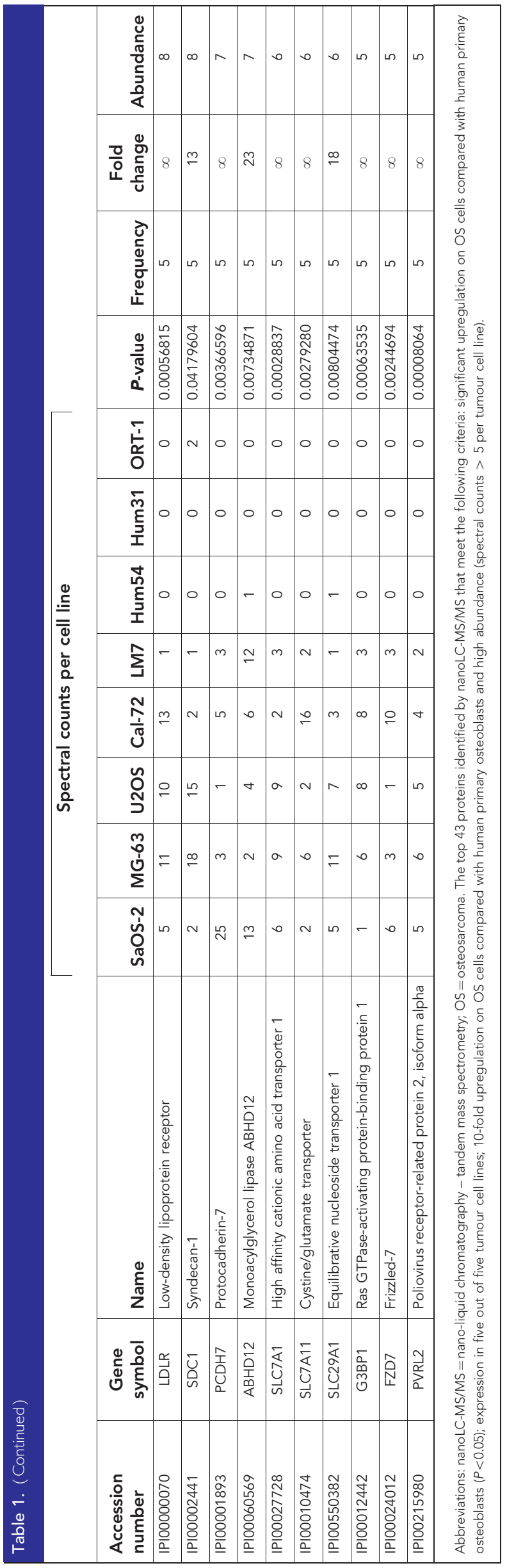

show significantly increased levels of EPHA2 compared with healthy bone $(P<0.005)$. As a majority of OS expressed EPHA2, this molecule can be considered a relevant receptor for targeted drug delivery to this tumour and targeting this receptor might be beneficial for a majority of patients.

EPHA2 is expressed in a majority of OS tumour samples and is associated with poor survival. To assess the clinical relevance of EPHA2 expression in OS and to investigate if EPHA2 could be considered a biomarker for OS, TMAs containing 647 cores of human primary OS samples were stained and analysed for EPHA2 expression. Every tumour was represented by three cores on the TMAs and certain patients were represented more than once on the TMA, that is, with cores corresponding to primary biopsies, first resections and resections of metastases and/or relapses. Staining results were correlated to clinical data. All samples were independently scored twice by two of the authors (JP and PWE) with high observer agreement (Supplementary Table S5). Owing to loss of tissue from the array slides as a result of the cutting and staining procedures, 200 cores were considered unsuitable for scoring, leaving 447 scored tissue cores for analysis. Eventually, 127 primary tumours were assigned a staining score. Of these, 85 tumours (67\%) showed EPHA2 positivity and 42 tumours (37\%) were EPHA2 negative. In addition, 33 metastatic lesions and 10 local relapses were assigned a staining score. These lesions showed an EPHA2 positivity of $58 \%$ and $40 \%$, respectively. To study the predictive value of EPHA2 staining on overall survival, we selected first biopsy and/or resection samples only; diagnostic biopsies had not been exposed to pre-operative chemotherapy while resection samples had been exposed to pre-operative chemotherapy. Samples of recurrences (both metastatic and local) were excluded to avoid confounding for inferior survival as a result of metastatic and/or recurrent disease. After applying these criteria, 68 patients remained eligible for analysis. Of the analysed patients, 57 (84\%) had EPHA2-positive and 11 (16\%) had EPHA2-negative tumours. Baseline characteristics did not differ significantly between the EPHA2-positive and EPHA2-negative tumours (Table 2). Figure 4 shows Kaplan-Meier curves of EPHA2-positive and EPHA2negative staining as predictor for overall survival. The difference in cumulative overall survival between patients with EPHA2-positive and EPHA2-negative tumours shows a trend towards inferior survival for patients with EPHA2-positive tumours (log rank, $P=0.065)$. Among 23 deceased patients, only one patient had an EPHA2-negative tumour $\left(\chi^{2}, P=0.058\right)$. Patients with EPHA2negative tumours showed a better survival outcome (mean 10.5 years) compared with patients with EPHA2-positive tumours (mean 8.7 years), however, this difference was not statistically significant. Also, EPHA2 staining did not significantly influence relapse $(P=0.580)$, response to chemotherapy $(P=0.743)$ or event-free survival $(P=0.273)$ in our data set. Thus, although EPHA2 staining only shows modest influence on several early clinical outcome parameters, EPHA2 positivity does seem to predict an unfavourable survival. More importantly, the majority of tested primary OS specimens express EPHA2, indicating that when applying targeted drug delivery towards this receptor, a majority of patients may benefit.

DISCUSSION

In this work, we conducted a comparative proteomic analysis of the cell surface proteomes of five OS cell lines and three osteoblast cultures in order to identify a receptor for the targeted delivery of treatment to OS. For this purpose, we combined the biotinylation of the cell surface for the isolation and retrieval of surface proteins with a high-resolution mass spectrometric analysis. Doing this, we obtained an extensive and robust data set that potentially 


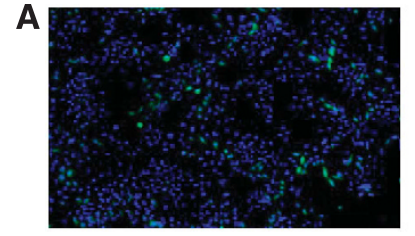

SaOS-2 MOI-1.6

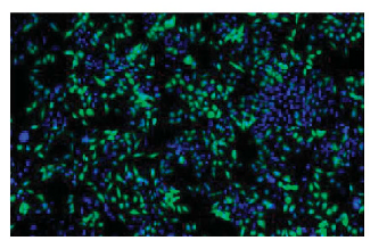

SaOS-2 MOI-6.25

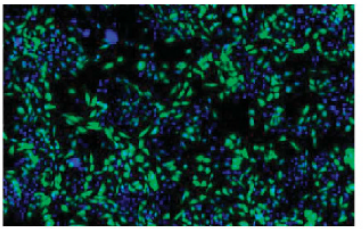

SaOS-2 MOI-25

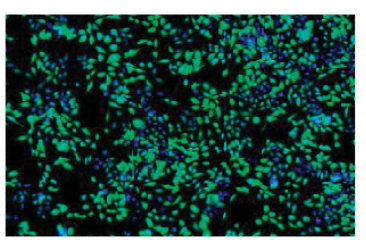

SaOS-2 MOI-100

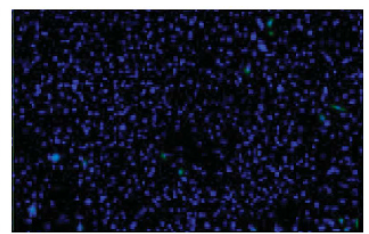

MG-63 MOI-1.6

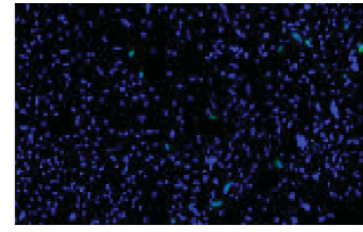

MG-63 MOI-6.25

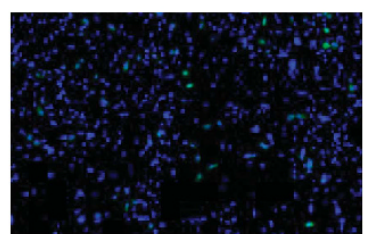

MG-63 MOI-25

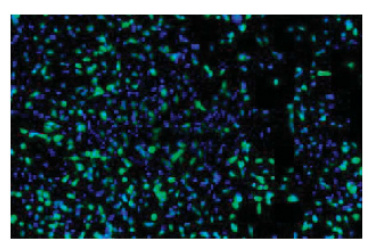

MG-63 MOI-100

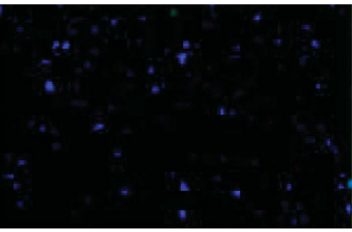

Hum63 MOI-1.6

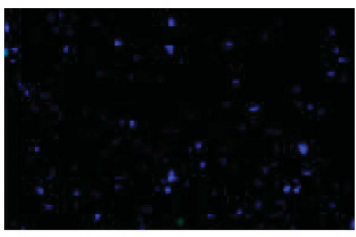

Hum63 MOI-6.25

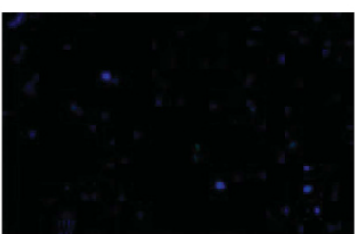

Hum63 MOI-25

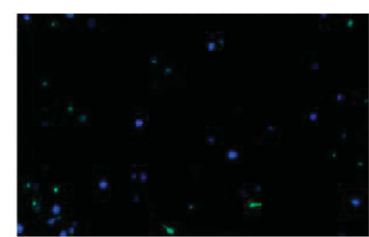

Hum63 MOI-100
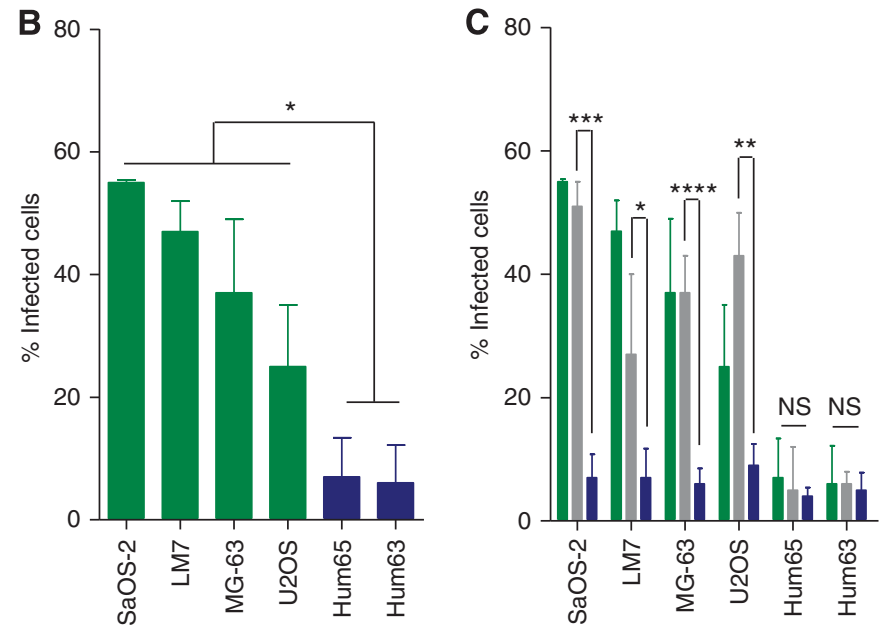

Figure 2. EPHA2 receptor specifically mediates targeted adenoviral vector internalisation into OS cells. (A) Representative fluorescence images of SaOS-2 and MG-63 OS cells and Hum63 hp-OBs subjected to transduction with AdYSA at the indicated MOls, acquired using the Acumen ${ }^{\text {XX3 }}$ microplate cytometer. Composite images show Hoechst-stained cell nuclei (blue) and GFP-expression (green). (B) Transduction of OS cell lines (green bars) and hp-OBs (blue bars) with EPHA2-targeted adenoviral vector AdYSA, as measured by GFP expression $48 \mathrm{~h}$ after subjecting the cells to virus at $\mathrm{MOI}-100$. Bars represent mean results of an experiment performed in triplicate; error bars indicate s.d. The observed difference between OS cells and hp-OBs is three- to six-fold (Student's $t$-test; ${ }^{*} P<0.05$ ). (C) Competition by pre-incubation of the cells with synthetic peptides before incubation with AdYSA. Bars represent mean results of an experiment performed in triplicate; error bars indicate s.d. Green bars represent the control condition in which the cells were incubated with AdYSA alone, grey bars represent the control condition in which cells were pre-incubated with Cys.S peptide, followed by incubation with AdYSA and blue bars represent the competition condition in which cells were pre-incubated with YSA peptide followed by incubation with AdYSA. Receptor blocking with YSA peptide results in significant reduction of

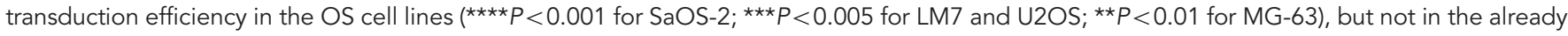
poorly transduced healthy bone cells (NS).

harbours various interesting novel biomarkers or treatment targets for OS.

The number of published proteomic studies investigating OS is limited. Previous research includes efforts to unravel OS development, to study mechanisms of drug response, to identify new biomarkers for prognosis and therapy response, and, to identify putative therapeutic candidates for OS by studying differences within the entire proteome of OS cells or cell lines compared with human osteoblasts (Guo et al, 2007a; Folio et al, 2009; Liu et al, 2009; Zhang et al, 2009). 


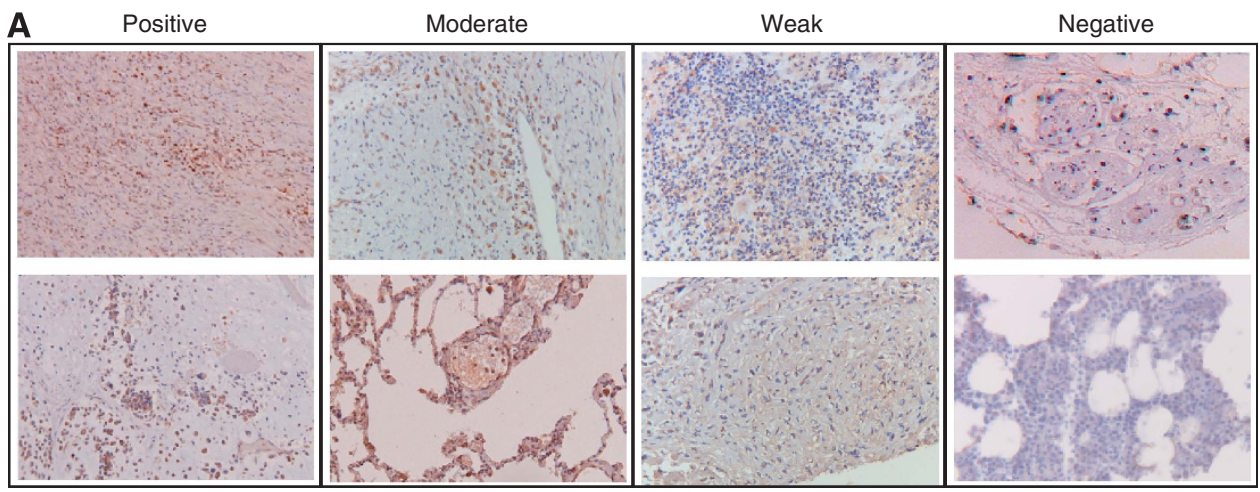

\begin{tabular}{lcccc}
\hline Summary: & & & & \\
\hline \hline & $\begin{array}{c}\text { Bone } \\
(n=11)\end{array}$ & $\begin{array}{c}\text { OS } \\
(n=18)\end{array}$ & $\begin{array}{c}\text { Primary } \\
(n=10)\end{array}$ & $\begin{array}{c}\text { Metastatic } \\
(n=8)\end{array}$ \\
\hline Positive & - & 12 & 5 & 7 \\
Moderate & 1 & 4 & 4 & - \\
Weak & 2 & - & - & - \\
Negative & 7 & 2 & 1 & 1 \\
NA & 1 & & & $P=0.004$ \\
\hline$\chi^{2}$ & $P=0.0046$ & & $P=0.0023$ \\
\hline
\end{tabular}

Figure 3. EPHA2 is expressed on human OS tissue. (A) Immunohistochemical staining results for EPHA2 on human OS and normal bone tissue sections. Per category, two examples are shown. (B) Tissue staining per group. Staining was scored based on the percentage of positive cells and the intensity of the staining of the cells and allotted to the categories: negative, weak, moderate or positive. One bone sample could not be scored because of limited sample quality (NA). The staining intensity was significantly higher in the OS samples compared with healthy bone tissue, both in the primary and metastatic lesions $\left(\chi^{2} ;{ }^{\star \star \star} P<0.005\right)$. Clinical details of all samples are provided in Supplementary Table S5.

To study the surface proteome of OS cells, we used an in-depth, high-resolution approach combining cell surface biotinylation for the isolation and retrieval of plasma membrane proteins, gel fractionation and mass spectrometric analysis using nano-liquid chromatography - tandem mass spectrometry (nanoLC-MS/MS)based proteomics. Typically, surface proteomics analysis consists of surface biotinylation and surface protein purification, protein solubilisation, protein and/or peptide fractionation, peptide digestion and extraction, tandem mass spectrometry and database searching and protein identification and quantification $(\mathrm{Wu}$ and Yates, III, 2003; Pham et al, 2010). Although plasma membrane proteins have fundamental roles in tumour biology, they tend to be underrepresented in data sets, especially in the studies that used 2D gel-electrophoresis for protein fractionation. In part, this is attributable to their composition with both hydrophobic and hydrophilic regions, which poses solubility issues in the workup of surface proteins for experimental analyses. In addition, membrane proteins are mostly low-abundant and therefore high-abundant intracellular proteins could potentially overshadow the presence of low-abundant surface proteins, thereby hampering their identification and quantification. To subvert these issues, we performed an enrichment of surface proteins by surface biotinylation (Wu and Yates, III, 2003; Scheurer et al, 2005; De Wit et al, 2012) and a protein fractionation method highly compatible with membrane proteins (SDS-PAGE) before our nanoLC-MS/MS analysis. To our knowledge, this is the first report of cell surface proteomics in OS in a panel of cell lines. Two recent studies reported a preliminary proteomics analysis of the plasma membrane proteome of two OS cell types as isolated by a crude two-phase partitioning method in conjunction with a 2D gel-based analysis or an iTRAQLC-MS/MS-based approach (Zhang et al, 2010; Hua et al, 2011). Importantly, the key molecules that were selected in these studies as putative biomarkers (i.e., NDRG1 and CD151) out of relatively small data sets (343 proteins in the study of Zhang et al and 7 proteins in the study of $\mathrm{Hua}$ et al) are also regulated in our extended cell surface proteome data set, retrieved in a panel of five OS cell lines. Such independent, bilateral verification adds to the robustness of our data set. Furthermore, our hitlist contains several well known cell surface proteins that were previously reported to be expressed and of biological importance in OS, supporting the relevance of our obtained data set. These proteins include the insulin growth factor receptor 1 (Mansky et al, 2002; Kolb et al, 2010) and insulin receptor (INSR); (Avnet et al, 2009) that have been reported to stimulate tumour growth in OS; the Wnt-receptor family member Frizzled-7 receptor that is involved in survival, migration and disease progression in OS (Guo et al, 2007b, 2008; Chen et al, 2008; Cai et al, 2010; McQueen et al, 2011); integrin- $\alpha 4$, described to be of influence on cell survival in OS (Marco et al, 2003) and integrin- $\beta 4$ that has previously been reported to colocalise with ezrin and enhance OS metastasis (Wan et al, 2009); and, finally, ephrin receptors (EPHA2, EPHB2 and EPHB4) that have been previously implicated in tumour growth and prognosis in OS (Varelias et al, 2002; Abdou et al, 2010; FritscheGuenther et al, 2010).

Ephrin type-A receptor 2 was the most abundant upregulated cell surface receptor in our data set and thus we chose this molecule for follow-up investigations. Ephrin type-A receptor 2 is a cell surface receptor of the erythropoietin-producing hepatocellular (Eph) tyrosine kinases receptor family and is reported to be overexpressed in various types of cancer, while being comparatively lowly expressed in normal tissues (Pasquale, 2010; Tandon et al, 2011; Udayakumar et al, 2011). Binding of EPHA2 to its corresponding ligand (EphrinA1), causes receptor phosphorylation and subsequent internalisation and degradation. Phosphorylation of the receptor results in downstream signalling via several well known kinases (PI3K, FAK, Akt, RHOA, MEK, Src family- and 


\section{Table 2. Clinical characteristics and outcome data classified according to EPHA2 staining}

\begin{tabular}{|c|c|c|c|c|}
\hline Categorical & $\mathbf{N}$ total & EPHA2 negative & EPHA2 positive & $\boldsymbol{P}$-value \\
\hline \multicolumn{5}{|l|}{ Gender } \\
\hline $\begin{array}{l}\text { Female } \\
\text { Male }\end{array}$ & $\begin{array}{l}35 \\
33\end{array}$ & $\begin{array}{l}5 \\
6\end{array}$ & $\begin{array}{l}30 \\
27\end{array}$ & 0.663 \\
\hline \multicolumn{5}{|l|}{ Location } \\
\hline $\begin{array}{l}\text { Femur } \\
\text { Humerus } \\
\text { Tibia/fibula } \\
\text { Other }\end{array}$ & $\begin{array}{r}36 \\
7 \\
23 \\
2\end{array}$ & $\begin{array}{l}7 \\
2 \\
2 \\
0\end{array}$ & $\begin{array}{r}29 \\
5 \\
21 \\
2\end{array}$ & 0.491 \\
\hline \multicolumn{5}{|l|}{ Side } \\
\hline $\begin{array}{l}\text { Left } \\
\text { Right }\end{array}$ & $\begin{array}{l}35 \\
33\end{array}$ & $\begin{array}{l}6 \\
5\end{array}$ & $\begin{array}{l}29 \\
28\end{array}$ & 0.824 \\
\hline \multicolumn{5}{|l|}{ Relapse } \\
\hline $\begin{array}{l}\text { No } \\
\text { Yes }\end{array}$ & $\begin{array}{l}48 \\
20\end{array}$ & $\begin{array}{l}7 \\
4\end{array}$ & $\begin{array}{l}41 \\
16\end{array}$ & 0.580 \\
\hline \multicolumn{5}{|c|}{ Chemotherapy response } \\
\hline $\begin{array}{l}\text { Poor } \\
\text { Good }\end{array}$ & $\begin{array}{l}34 \\
21\end{array}$ & $\begin{array}{l}6 \\
3\end{array}$ & $\begin{array}{l}28 \\
18\end{array}$ & 0.743 \\
\hline Huvos 1 & 8 & 0 & 8 & \\
\hline Huvos 2 & 26 & 6 & 20 & \\
\hline Huvos 3 & 18 & 2 & 16 & \\
\hline Huvos 4 & 3 & 1 & 2 & \\
\hline & & & & 0.332 \\
\hline \multicolumn{5}{|l|}{ Survival } \\
\hline $\begin{array}{l}\text { Alive } \\
\text { Deceased }\end{array}$ & $\begin{array}{l}45 \\
23\end{array}$ & $\begin{array}{r}10 \\
1\end{array}$ & $\begin{array}{l}35 \\
22\end{array}$ & 0.058 \\
\hline
\end{tabular}

\begin{tabular}{|c|c|c|c|c|c|c|c|c|}
\hline \multirow[b]{2}{*}{ Numerical } & \multirow[b]{2}{*}{$\mathbf{N}$ total } & \multicolumn{3}{|c|}{ EPHA2 negative } & \multicolumn{3}{|c|}{ EPHA2 positive } & \multirow[b]{2}{*}{$\boldsymbol{P}$-value } \\
\hline & & Mean & S.d & Range & mean & S.d. & Range & \\
\hline \multicolumn{9}{|l|}{ Age (years) } \\
\hline $\begin{array}{l}\text { Diagnosis } \\
\text { Death }\end{array}$ & $\begin{array}{l}63 \\
23\end{array}$ & $\begin{array}{l}14.6 \\
17.6\end{array}$ & $\begin{array}{l}3.5 \\
-\end{array}$ & $\begin{array}{c}(7.9-19.2) \\
-\end{array}$ & $\begin{array}{l}15.0 \\
16.4\end{array}$ & $\begin{array}{l}5.0 \\
4.4\end{array}$ & $\begin{array}{l}(5.6-36.8) \\
(7.0-25.9)\end{array}$ & $\begin{array}{l}0.842 \\
0.803\end{array}$ \\
\hline Follow-up (Months) & 63 & 115.5 & 98.4 & $(11-267)$ & 70.1 & 3.0 & (3-258) & 0.084 \\
\hline Event-free survival (Months) & 32 & 2.5 & 4.4 & $(0.0-7.6)$ & 9.7 & 11.0 & $(0.0-40.2)$ & 0.273 \\
\hline \multicolumn{9}{|l|}{ Overall survival (years) } \\
\hline Alive & 40 & 10.5 & 8.1 & $(1.2-22.3)$ & 8.7 & 6.6 & $(1.2-21.5)$ & 0.491 \\
\hline Deceased & 23 & 0.9 & - & - & 1.9 & 1.2 & $(0.3-4.6)$ & 0.428 \\
\hline
\end{tabular}

MAP-kinases), influencing multiple fundamental processes such as cell morphology, adhesion, proliferation, differentiation, survival, migration, invasion and metastasis. In addition, EPHA2 induces angiogenesis (Fritsche-Guenther et al, 2010; Pasquale, 2010; Tandon et al, 2011; Udayakumar et al, 2011). The substantially higher expression levels of EPHA2 on OS compared with healthy bone, in addition to its role in cancer progression, implies that EPHA2 could be a suitable therapeutic target itself and this has been the topic of studies in several malignancies. Preclinical studies in various tumour models showed that targeting of EPHA2 using 


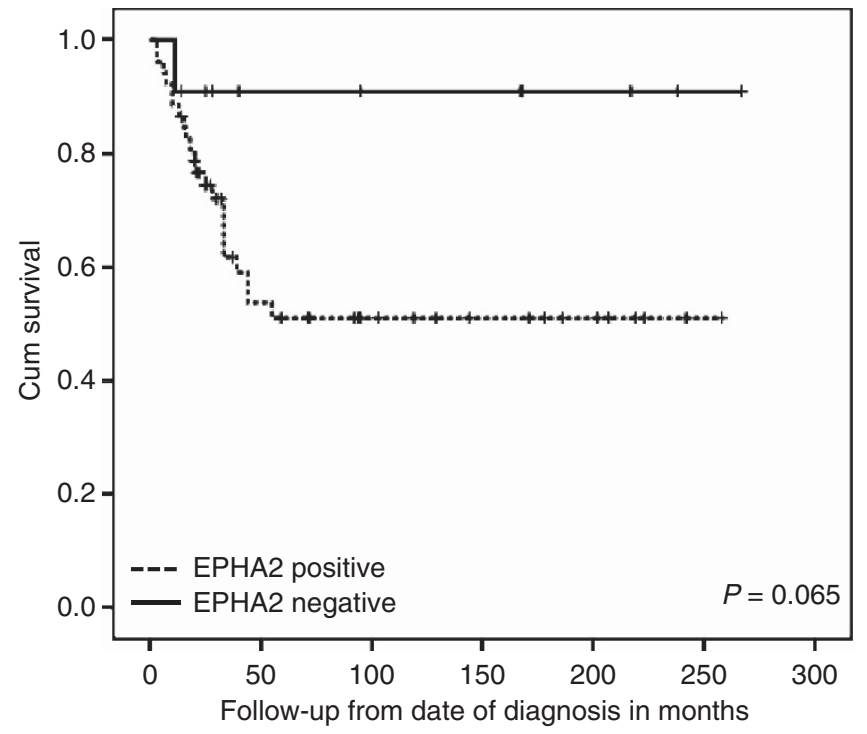

Figure 4. Kaplan-Meier curves showing overall survival of OS patients with EPHA2-positive or EPHA2-negative tumours. Kaplan-Meier survival plot showing the cumulative survival of patients suffering from localised OS. Patients were divided into two groups of patients with EPHA2-positive tumours (57 samples) and those with EPHA2negative tumours (11 samples). The observed difference in the probability of survival between the two groups shows a trend towards inferior survival for patients with positive EPHA2 staining (log rank; $P=0.065)$.

antibodies or RNAi techniques led to reduced tumourigenicity and restored treatment sensitivity in vitro and in vivo (Landen et al, 2005; Hammond et al, 2007; Pasquale, 2010; Tandon et al, 2011; Udayakumar et al, 2011). Although some studies report that EPHA2 receptor binding, internalisation and degradation influences cell survival, we did not observe a cytotoxic effect of incubation with AdYSA. It might be that binding and internalisation of EPHA2 alone is not sufficient to affect OS cell survival and that additional stimuli are needed. Furthermore, in previous work performed in our group, we conducted an siRNA screen in which we analysed the effect of gene-silencing of kinases and kinaseassociated genes on the viability of OS cells (PosthumaDeBoer et al, 2012). The tested library also contained siRNA targeting EPHA2. The results obtained in this screen showed no significant decrease in cell viability upon silencing of EPHA2. Thus, we have evidence suggesting that EPHA2 silencing in OS cells does not influence proliferation rates or cell viability. Nonetheless, it will be interesting to investigate whether EPHA2 could be used as a therapeutic target itself via targeting with other treatment modalities in OS.

Literature on EPHA2 expression in OS is extremely limited, however, recently Fritsche-Guenther et al (2010) reported EPHA2 mRNA overexpression in OS and speculated that this receptor could be a therapeutic target for the treatment of OS. In our study, we used an unbiased, comprehensive mass spectrometry approach to study the OS surface proteome and independently observed EPHA2 receptor overexpression in OS. We could thus conclude that increased EPAH2 gene expression translates into elevated EPHA2 surface protein levels in OS. Furthermore, we found EPHA2 receptor expression in human OS patient material. In our studies on 18 archival OS tumour sections and 146 tumour sections on TMAs, we found that the majority of the analysed tumours expressed EPHA2. We then proceeded to assess the potential clinical relevance of EPHA2 expression in patients. For this purpose, we correlated EPHA2 staining to clinical parameters.
At present, there is no specific predictive or prognostic marker for OS (Gorlick et al, 2003). Ephrin type-A receptor 2 expression in tumours has been linked to increased malignancy and reduced survival rates in previous studies (Landen et al, 2005; Pasquale, 2010; Tandon et al, 2011). The Kaplan-Meier analysis of patients with EPHA2-positive vs EPHA2-negative tumours showed a trend toward inferior survival in patients with EPHA2-expressing tumours $(P=0.065)$. We could not find significant differences nor trends between EPHA2-positive and EPHA2-negative tumours in terms of relapse rate, response to chemotherapy or event-free survival. A possible explanation would be the limited number of patients analysed and the relative disproportion between the number of EPHA2-positive (57) and EPHA2-negative (11) tumours. Our findings suggest that possibly EPHA2 could be a predictor for inferior survival of OS patients deriving from the trend that we observed in our data set. However, given the fact that this did not reach statistical significance in our relatively small number of samples, this observation needs further confirmation in a larger, independent data set.

Our focus was centred on researching the possibility to use EPHA2 as a receptor for the targeted delivery of therapeutic moieties to OS. The use of EPHA2 for this purpose was studied previously in other cancer types. In preclinical models of gynaecological malignancies, immunoconjugates were reported to specifically bind and reduce the viability of EPHA2-expressing cells (Lee et al, 2010). Apart from antibody-based targeting, the synthetic YSA peptide can also efficiently direct various moieties to the EPHA2 receptor. Recently, Mitra et al (2010) elucidated functional properties of the YSA peptide as a specific binding molecule to EPHA2 with subsequent downstream signalling events in a prostate cancer cell line. Dickerson et al (2010) described the use of hydrogel nanoparticles coated with YSA peptide for the specific delivery of siRNA to EPHA2-expressing tumour cells, with the aim of enhancing chemosensitivity. YSA has also been coupled to magnetic nanoparticles that were used to specifically bind EPHA2-expressing tumour cells and clear these cells from the circulation and peritoneal fluid of tumour-bearing mice using a strong magnetic field (Scarberry et al, 2008). In this work we showed, in line with previous work in pancreatic cancer (Van Geer et al, 2009, 2010), that YSA peptide-carrying adenoviral vectors can be internalised efficiently and specifically by EPHA2-expressing OS cells. This could provide a promising strategy to deliver therapy to the tumour rather than to healthy tissues and thus realise a selective anticancer therapy. Importantly, EPHA2 was found expressed in a majority of OS tumour samples, implying that EPHA2 can be considered a clinically relevant molecule for the targeted delivery of drugs to OS, and that exploitation of EPHA2 as a receptor for drug delivery could be beneficial to a majority of OS patients. Future development of EPHA2 as a receptor for targeted drug delivery would need confirmation of our findings in an animal model of OS, to investigate whether the specific delivery and uptake of EPHA2-targeted moieties can also be realised in vivo.

In summary, the combined knowledge discussed above plus the new findings that we have presented in this work lead us to conclude that targeted delivery of therapeutic agents via the EPHA2 receptor could be a useful strategy to increase the efficacy of OS treatment.

\section{ACKNOWLEDGEMENTS}

We kindly acknowledge Meike de Wit for her advice and guidance on cell surface protein isolation and Silvina Fratantoni for her technical assistance. JP is supported by the Individualised Musculoskeletal Regeneration and Reconstruction Network 
(Danish Research Council), Aarhus, Denmark; and by VONK: VUmc Onderzoek naar Kinderkanker, Amsterdam, The Netherlands. TVP, CRJ and the proteomics infrastructure were supported by the VUmc Cancer Center Amsterdam.

\section{CONFLICT OF INTEREST}

The authors declare no conflict of interest.

\section{AUTHOR CONTRIBUTIONS}

JP performed the experiments, interpreted experimental data, conceived and drafted the manuscript. SRP performed the mass spectrometry and protein identification and quantification. TVP performed statistical analysis of the proteomics data. PWE performed analysis and correlations of tissue staining and clinical data. JCK performed the data mining, network and gene ontology analyses. AMC provided TMAs and clinical data. MAG provided AdYSA and YSA peptide. VWB helped design experimental set-up, data interpretation, critically reviewed and corrected the manuscript. BJR and GJLK reviewed and corrected the manuscript. $\mathrm{CRJ}$ and $\mathrm{MNH}$ supervised the project, helped design experiments and interpret experimental data and critically reviewed the contents of the manuscript. All authors read and approved the final manuscript.

\section{REFERENCES}

Abdou AG, Abd el-Wahed MM, Asaad NY, Samaka RM, Abdallaha R (2010) Ephrin A4 expression in osteosarcoma, impact on prognosis, and patient outcome. Indian J Cancer 47: 46-52.

Albrethsen J, Knol JC, Piersma SR, Pham TV, de Wit M, Mongera S, Carvalho B, Verheul HM, Fijneman RJ, Meijer GA, Jimenez CR (2010) Subnuclear proteomics in colorectal cancer: identification of proteins enriched in the nuclear matrix fraction and regulation in adenoma to carcinoma progression. Mol Cell Proteomics 9: 988-1005.

Altman DG (1991) Practical Statistics for Medical Research. Chapmann \& Hall: London.

Avnet S, Sciacca L, Salerno M, Gancitano G, Cassarino MF, Longhi A, Zakikhani M, Carboni JM, Gottardis M, Giunti A, Pollak M, Vigneri R, Baldini N (2009) Insulin receptor isoform A and insulin-like growth factor II as additional treatment targets in human osteosarcoma. Cancer Res 69: 2443-2452.

Bielack SS, Kempf-Bielack B, Delling G, Exner GU, Flege S, Helmke K, Kotz R, Salzer-Kuntschik M, Werner M, Winkelmann W, Zoubek A, Jurgens H, Winkler K (2002) Prognostic factors in high-grade osteosarcoma of the extremities or trunk: an analysis of 1,702 patients treated on neoadjuvant cooperative osteosarcoma study group protocols. J Clin Oncol 20: 776-790.

Cai Y, Mohseny AB, Karperien M, Hogendoorn PC, Zhou G, Cleton-Jansen AM (2010) Inactive Wnt/beta-catenin pathway in conventional high-grade osteosarcoma. J Pathol 220: 24-33.

Chen K, Fallen S, Abaan HO, Hayran M, Gonzalez C, Wodajo F, MacDonald T, Toretsky JA, Uren A (2008) Wnt10b induces chemotaxis of osteosarcoma and correlates with reduced survival. Pediatr Blood Cancer 51: 349-355.

Cox J, Mann M (2007) Is proteomics the new genomics? Cell 130: 395-398.

De Wit M, Jimenez CR, Carvalho B, Belien JA, Delis-van Diemen PM, Mongera S, Piersma SR, Vikas M, Navani S, Ponten F, Meijer GA, Fijneman RJ (2012) Cell surface proteomics identifies glucose transporter type 1 and prion protein as candidate biomarkers for colorectal adenomato-carcinoma progression. Gut 61: 855-864.

Dickerson EB, Blackburn WH, Smith MH, Kapa LB, Lyon LA, McDonald JF (2010) Chemosensitization of cancer cells by siRNA using targeted nanogel delivery. BMC Cancer 10: 10.

Folio C, Mora MI, Zalacain M, Corrales FJ, Segura V, Sierrasesumaga L, Toledo G, San-Julian M, Patino-Garcia A (2009) Proteomic analysis of chemonaive pediatric osteosarcomas and corresponding normal bone reveals multiple altered molecular targets. J Proteome Res 8: 3882-3888.

Fritsche-Guenther R, Noske A, Ungethum U, Kuban RJ, Schlag PM, Tunn PU, Karle J, Krenn V, Dietel M, Sers C (2010) De novo expression of EphA2 in osteosarcoma modulates activation of the mitogenic signalling pathway. Histopathology 57: 836-850.

Gorlick R, Anderson P, Andrulis I, Arndt C, Beardsley GP, Bernstein M, Bridge J, Cheung NK, Dome JS, Ebb D, Gardner T, Gebhardt M, Grier H, Hansen M, Healey J, Helman L, Hock J, Houghton J, Houghton P, Huvos A, Khanna C, Kieran M, Kleinerman E, Ladanyi M, Lau C, Malkin D, Marina N, Meltzer P, Meyers P, Schofield D, Schwartz C, Smith MA, Toretsky J, Tsokos M, Wexler L, Wigginton J, Withrow S, Schoenfeldt M, Anderson B (2003) Biology of childhood osteogenic sarcoma and potential targets for therapeutic development: meeting summary. Clin Cancer Res 9: 5442-5453.

Guo QC, Shen JN, Jin S, Wang J, Huang G, Zhang LJ, Huang G, Yin JQ, Zou CY, Li MT (2007a) Comparative proteomic analysis of human osteosarcoma and SV40-immortalized normal osteoblastic cell lines. Acta Pharmacol Sin 28: 850-858.

Guo Y, Rubin EM, Xie J, Zi X, Hoang BH (2008) Dominant negative LRP5 decreases tumorigenicity and metastasis of osteosarcoma in an animal model. Clin Orthop Relat Res 466: 2039-2045.

Guo Y, Zi X, Koontz Z, Kim A, Xie J, Gorlick R, Holcombe RF, Hoang BH (2007b) Blocking Wnt/LRP5 signaling by a soluble receptor modulates the epithelial to mesenchymal transition and suppresses met and metalloproteinases in osteosarcoma Saos-2 cells. J Orthop Res 25: 964-971.

Hammond SA, Lutterbuese R, Roff S, Lutterbuese P, Schlereth B, Bruckheimer E, Kinch MS, Coats S, Baeuerle PA, Kufer P, Kiener PA (2007) Selective targeting and potent control of tumor growth using an EphA2/CD3Bispecific single-chain antibody construct. Cancer Res 67: 3927-3935.

Hua Y, Jia X, Sun M, Zheng L, Yin L, Zhang L, Cai Z (2011) Plasma membrane proteomic analysis of human osteosarcoma and osteoblastic cells: revealing NDRG1 as a marker for osteosarcoma. Tumour Biol 32 1013-1021.

Hughes DP (2009) Strategies for the targeted delivery of therapeutics for osteosarcoma. Expert Opin Drug Deliv 6: 1311-1321.

Jia SF, Worth LL, Kleinerman ES (1999) A nude mouse model of human osteosarcoma lung metastases for evaluating new therapeutic strategies. Clin Exp Metastasis 17: 501-506.

Kansara M, Thomas DM (2007) Molecular pathogenesis of osteosarcoma. DNA Cell Biol 26: 1-18.

Khanna C, Wan X, Bose S, Cassaday R, Olomu O, Mendoza A, Yeung C, Gorlick R, Hewitt SM, Helman LJ (2004) The membrane-cytoskeleton linker ezrin is necessary for osteosarcoma metastasis. Nat Med 10: 182-186.

Kim SY, Lee CH, Midura BV, Yeung C, Mendoza A, Hong SH, Ren L, Wong D, Korz W, Merzouk A, Salari H, Zhang H, Hwang ST, Khanna C, Helman LJ (2008) Inhibition of the CXCR4/CXCL12 chemokine pathway reduces the development of murine pulmonary metastases. Clin Exp Metastasis 25: 201-211.

Kolb EA, Kamara D, Zhang W, Lin J, Hingorani P, Baker L, Houghton P, Gorlick R (2010) R1507, a fully human monoclonal antibody targeting IGF-1R, is effective alone and in combination with rapamycin in inhibiting growth of osteosarcoma xenografts. Pediatr Blood Cancer 55: 67-75.

Krishnan K, Khanna C, Helman LJ (2005) The biology of metastases in pediatric sarcomas. Cancer J 11: 306-313.

Landen Jr CN, Chavez-Reyes A, Bucana C, Schmandt R, Deavers MT, LopezBerestein G, Sood AK (2005) Therapeutic EphA2 gene targeting in vivo using neutral liposomal small interfering RNA delivery. Cancer Res 65: 6910-6918.

Landis JR, Koch GG (1977) The measurement of observer agreement for categorical data. Biometrics 33: 159-174.

Lee JW, Stone RL, Lee SJ, Nam EJ, Roh JW, Nick AM, Han HD, Shahzad MM, Kim HS, Mangala LS, Jennings NB, Mao S, Gooya J, Jackson D, Coleman RL, Sood AK (2010) EphA2 targeted chemotherapy using an antibody drug conjugate in endometrial carcinoma. Clin Cancer Res 16: 2562-2570.

Liu X, Zeng B, Ma J, Wan C (2009) Comparative proteomic analysis of osteosarcoma cell and human primary cultured osteoblastic cell. Cancer Invest 27: 345-352.

Lund R, Leth-Larsen R, Jensen ON, Ditzel HJ (2009) Efficient isolation and quantitative proteomic analysis of cancer cell plasma membrane proteins for identification of metastasis-associated cell surface markers. J Proteome Res 8: 3078-3090. 
Mansky PJ, Liewehr DJ, Steinberg SM, Chrousos GP, Avila NA, Long L, Bernstein D, Mackall CL, Hawkins DS, Helman LJ (2002) Treatment of metastatic osteosarcoma with the somatostatin analog OncoLar: significant reduction of insulin-like growth factor-1 serum levels. J Pediatr Hematol Oncol 24: 440-446.

Marco RA, Diaz-Montero CM, Wygant JN, Kleinerman ES, McIntyre BW (2003) Alpha 4 integrin increases anoikis of human osteosarcoma cells. J Cell Biochem 88: 1038-1047.

McQueen P, Ghaffar S, Guo Y, Rubin EM, Zi X, Hoang BH (2011) The Wnt signaling pathway: implications for therapy in osteosarcoma. Expert Rev Anticancer Ther 11: 1223-1232.

Mitra S, Duggineni S, Koolpe M, Zhu X, Huang Z, Pasquale EB (2010) Structure-activity relationship analysis of peptides targeting the EphA2 receptor. Biochemistry 49: 6687-6695.

Mohseny AB, Szuhai K, Romeo S, Buddingh EP, Briaire-de Bruijn I, de Jong D, van Pel M, Cleton-Jansen AM, Hogendoorn PC (2009) Osteosarcoma originates from mesenchymal stem cells in consequence of aneuploidization and genomic loss of Cdkn2. J Pathol 219: 294-305.

Pasquale EB (2010) Eph receptors and ephrins in cancer: bidirectional signalling and beyond. Nat Rev Cancer 10: 165-180.

Pham TV, Piersma SR, Oudgenoeg G, Jimenez CR (2012) Label-free mass spectrometry-based proteomics for biomarker discovery and validation. Expert Rev Mol Diagn 12: 343-359.

Pham TV, Piersma SR, Warmoes M, Jimenez CR (2010) On the beta-binomial model for analysis of spectral count data in label-free tandem mass spectrometry-based proteomics. Bioinformatics 26: 363-369.

Piersma SR, Fiedler U, Span S, Lingnau A, Pham TV, Hoffmann S, Kubbutat MH, Jimenez CR (2010) Workflow comparison for label-free, quantitative secretome proteomics for cancer biomarker discovery: method evaluation, differential analysis, and verification in serum. J Proteome Res 9: 1913-1922.

PosthumaDeBoer J, van Egmond PW, Helder MN, de Menezes RX, CletonJansen AM, Belien JA, Verheul HM, van Royen BJ, Kaspers GJ, Van Beusechem VW (2012) Targeting JNK-interacting-protein-1 (JIP1) sensitises osteosarcoma to doxorubicin. Oncotarget 3: 1169-1181.

Rochet N, Dubousset J, Mazeau C, Zanghellini E, Farges MF, de Novion HS, Chompret A, Delpech B, Cattan N, Frenay M, Gioanni J (1999) Establishment, characterisation and partial cytokine expression profile of a new human osteosarcoma cell line (CAL 72). Int J Cancer 82: 282-285.

Rosen G, Caparros B, Huvos AG, Kosloff C, Nirenberg A, Cacavio A, Marcove RC, Lane JM, Mehta B, Urban C (1982) Preoperative chemotherapy for osteogenic sarcoma: selection of postoperative adjuvant chemotherapy based on the response of the primary tumor to preoperative chemotherapy. Cancer 49: 1221-1230.

Rubin EM, Guo Y, Tu K, Xie J, Zi X, Hoang BH (2010) Wnt inhibitory factor 1 decreases tumorigenesis and metastasis in osteosarcoma. Mol Cancer Ther 9: 731-741.
Scarberry KE, Dickerson EB, McDonald JF, Zhang ZJ (2008) Magnetic nanoparticle-peptide conjugates for in vitro and in vivo targeting and extraction of cancer cells. J Am Chem Soc 130: 10258-10262.

Scheurer SB, Rybak JN, Roesli C, Brunisholz RA, Potthast F, Schlapbach R, Neri D, Elia G (2005) Identification and relative quantification of membrane proteins by surface biotinylation and two-dimensional peptide mapping. Proteomics 5: 2718-2728.

Stevens TJ, Arkin IT (2000) Do more complex organisms have a greater proportion of membrane proteins in their genomes? Proteins 39: 417-420.

Tandon M, Vemula SV, Mittal SK (2011) Emerging strategies for EphA2 receptor targeting for cancer therapeutics. Expert Opin Ther Targets 15: 31-51.

Udayakumar D, Zhang G, Ji Z, Njauw CN, Mroz P, Tsao H (2011) Epha2 is a critical oncogene in melanoma. Oncogene 30: 4921-4929.

Van Geer MA, Bakker CT, Koizumi N, Mizuguchi H, Wesseling JG, Oude Elferink RP, Bosma PJ (2009) Ephrin A2 receptor targeting does not increase adenoviral pancreatic cancer transduction in vivo. World $J$ Gastroenterol 15: 2754-2762.

Van Geer MA, Brevoord D, Kuhlmann KF, Bakker CT, Mizuguchi H, Wesseling JG, Ten Kate FJ, Gouma DJ, Oude Elferink RP, Bosma PJ (2010) A fiber modified adenovirus vector that targets to the EphrinA2 receptor reveals enhanced gene transfer to ex vivo pancreatic cancer. Int J Oncol 36: 233-244.

Varelias A, Koblar SA, Cowled PA, Carter CD, Clayer M (2002) Human osteosarcoma expresses specific ephrin profiles: implications for tumorigenicity and prognosis. Cancer 95: 862-869.

Wan X, Kim SY, Guenther LM, Mendoza A, Briggs J, Yeung C, Currier D, Zhang H, Mackall C, Li WJ, Tuan RS, Deyrup AT, Khanna C, Helman L (2009) Beta4 integrin promotes osteosarcoma metastasis and interacts with ezrin. Oncogene 28: 3401-3411.

Wu CC, Yates III JR (2003) The application of mass spectrometry to membrane proteomics. Nat Biotechnol 21: 262-267.

Zhang YK, Zhang XH, Li JM, Sun dS, Yang Q, Diao DM (2009) A proteomic study on a human osteosarcoma cell line Saos-2 treated with diallyl trisulfide. Anticancer Drugs 20: 702-712.

Zhang Z, Zhang L, Hua Y, Jia X, Li J, Hu S, Peng X, Yang P, Sun M, Ma F, Cai Z (2010) Comparative proteomic analysis of plasma membrane proteins between human osteosarcoma and normal osteoblastic cell lines. BMC Cancer 10: 206.

This work is published under the standard license to publish agreement. After 12 months the work will become freely available and the license terms will switch to a Creative Commons AttributionNonCommercial-Share Alike 3.0 Unported License.

Supplementary Information accompanies this paper on British Journal of Cancer website (http://www.nature.com/bjc) 